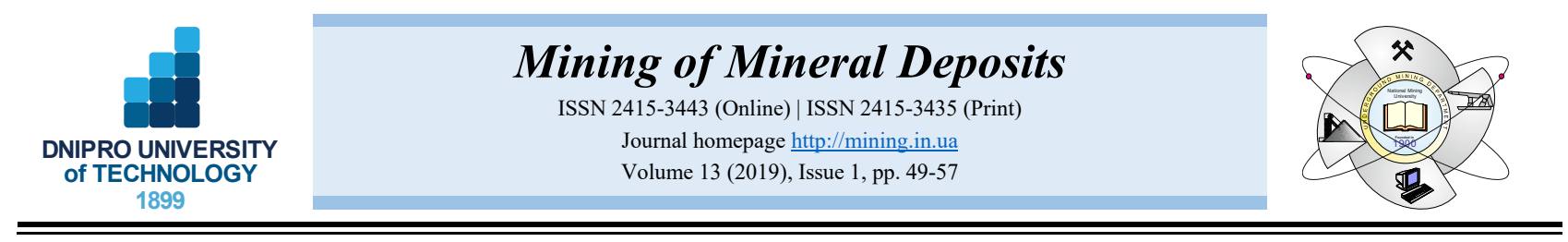

UDC 622.232 .5

https://doi.org/10.33271/mining13.01.049

\title{
REGULARITIES OF HYDROMECHANICAL AMBER EXTRACTION FROM SANDY DEPOSITS
}

\author{
Ye. Malanchuk ${ }^{1}$, V. Korniienko ${ }^{1}$, V. Moshynskyi ${ }^{1}$, V. Soroka ${ }^{1}$, A. Khrystyuk ${ }^{1}$, Z. Malanchuk ${ }^{1 *}$ \\ ${ }^{I}$ National University of Water and Environmental Engineering, Rivne, Ukraine \\ *Corresponding author: e-mail malanchykzr@ukr.net, tel.+380507774231
}

\begin{abstract}
Purpose is to analyze the efficiency of hydromechanical amber extraction from sandy deposits relying upon the determined regularities concerning the effect of parameters while carrying out a series of laboratory tests and fullscale experiments.

Methods. Laboratory tests and full-scale experiments (Volodymyrets amber-bearing deposit, village of Berezhnytsia) were carried out to analyze effect of the parameters of a hydromechanical technique on the velocity of amber extraction. The experiments also involved studies of occurrence medium; in this context, boiling process was modeled; and factors and parameters effecting suspense medium formation were researched. Methods of mathematical statistics were applied to obtain dependences describing mining parameters effect on amber extraction velocity.

Findings. Basic parameters of hydromechanical technique, effecting amber extraction velocity, have been determined. Efficient values of air supply to provide maximum velocity of amber floating have been identified. Mathematical dependences, determining amber floating velocity depending upon air supply and mechanical effect frequency, have been obtained. In this context, amber production capacity is 90 to $95 \%$. Basic parameters effecting amber mining (i.e. environmental density; amplitude of oscillations and their frequency; and water and air supply to sandy deposit of amber-bearing sand) have been defined.
\end{abstract}

Originality. It has been first proved that amber floating velocity is of polynomial nature dependence upon environmental density where extremum is with $0.004-0.006 \mathrm{~m}^{3} / \mathrm{h}$ air supply value; amber extraction experiences $2-3$ times intensification, if environmental density $\left(\rho_{c}\right)$ is $1670-1750 \mathrm{~kg} / \mathrm{m}^{3}$, oscillation frequency is $26-36 \mathrm{~Hz}$, amplitude is $A=1.0-2.4 \mathrm{~mm}$, and air supply is $q_{a}=0.004-0.006 \mathrm{~m}^{3} / \mathrm{h}$. In this context, amber floating $(v)$ is $0.09-0.12 \mathrm{~m} / \mathrm{s}$. If air supply is more than $q_{a}=0.020 \mathrm{~m}^{3} / \mathrm{h}$, amber extraction process stops. It has been first obtained polynomial dependence of amber flotation on oscillation frequency of operating device as well as on air supply to rock mass.

Practical implications. The determined regularities of hydromechanical amber extraction from amber-bearing sand help make calculations, and select facilities for hydromechanical amber mining.

Keywords: sandy deposit, amber, hydromechanical mining, air supply, floating velocity

\section{INTRODUCTION}

Current state of mineral mining in Rivne-Volyn region is characterized by the availability of a number of commercial deposits (Bulat, Naduty, \& Korniyenko, 2014; Sazonets \& Malanchuk, 2015), including amber ones. Some of them are being developed; others are not involved due to the fact that their operation is impossible with the use of traditional methods (Lozynskyi et al., 2018). Complicated mining and geological conditions (Malanchyk \& Korniyenko, 2014), significant remoteness from water bodies as well as necessity to preserve surface soil restrict their putting into operation involving extra recultivation activities (Krümmelbein, Horn, Raab,
Bens, \& Hüttl, 2010; Malanchuk, Korniienko, Malanchuk, Soroka, \& Vasylchuk, 2018).

Implementation of hydromechanical technique to mine minerals is the most promising solution involving no recultivation activities since the mineral is extracted in such a way to preserve surface soil with the help of hydraulic energy (Bondarenko, Lozynskyi, Sai, \& Anikushyna, 2015; Malanchuk, Korniyenko, Malanchuk, \& Khrystyuk, 2016). Maximum amber floating velocity, possible for certain deposit, will make it possible to reduce energy and water consumption, to increase mining efficiency, and to involve new promising deposits into operation (Li, 2014; Krek, Ulyanova, \& Koschavets, 2018).

(C) 2019. Ye. Malanchuk, V. Korniienko, V. Moshynskyi, V. Soroka, A. Khrystyuk, Z. Malanchuk. Published by the Dnipro University of Technology on behalf of Mining of Mineral Deposits. This is an Open Access article distributed under the terms of the Creative Commons Attribution License (http://creativecommons.org/licenses/by/4.0/),

which permits unrestricted reuse, distribution, and reproduction in any medium, provided the original work is properly cited. 
Papers by known scholars describe amber floating process in the context of its hydromechanical mining from sandy deposits mostly experimentally (Seyfullah, Sadowski, \& Schmidt, 2015; Havelcová et al., 2016; Poulin \& Helwig, 2016; Van der Werf, Fico, De Benedetto, \& Sabbatini, 2016). Hence, scientifically grounded models, determining dependence between particle flotation velocity, and physical and particle-size characteristics of a deposit as well as between oscillation frequency of operating device and air consumption, are not available. That makes it impossible for new deposits to determine efficient amber floating velocities and air consumption, supporting the process, without numerous experiments. Factors, effecting both efficiency and reliability of the available methods in the process of formation of such deposits and their development, have been singled out (Naduty, Malanchuk, Malanchuk, \& Korniyenko, 2016; Malanchuk, Moshynskyi, Malanchuk, \& Korniienko, 2018).

To substantiate calculation techniques for the parameters of hydromechanical method applied to extract amber from sandy deposits taking into consideration the factors, the calculation techniques, proposed by known scholars and experts from leading institutes of rock mechanics have been analyzed (Korniyenko, Malanchuk, Soroka, \& Khrystyuk, 2018). At the same time, available technical means to implement a process of hydromechanical amber mining cannot satisfy fully the demands; i.e. the developed techniques cannot guarantee complete mining of commercial component from enclosing rocks. Moreover, they do not always use working liquid efficiently.

Analysis of the studies means that many researchers were engaged in the problems of the development of hydromining methods; however, differences in a mineral occurrence and composition prevented from making universal quantitative conclusions. To make the quantitative solutions practical, the physical assumptions, forming the basis of the analysis, should comfort with environment in accordance with the accepted values (Lozynskyi, Dychkovskyi, Falshtynskyi, Saik, \& Malanchuk, 2016; Saik, Dychkovskyi, Lozynskyi, Malanchuk, \& Malanchuk, 2016). That also makes it possible to conclude that the required comprehensive analysis of choice and comparative evaluation of systems to test and mine on the basis of scientific approaches is not available (Burnashov, Chubarenko, \& Stont, 2010; Alekseev, 2013; Paynter \& Jackson, 2018).

Moreover, variety of mineral deposits, stages of their commercial development, and operational conditions determine the necessity of scientific rationale to apply the systems as well as identification of their economic performance helping select and make comparative evaluation (Haldar, 2013; Radwanek-Bąk, \& Nieć, 2015). In this context, opened occurrence of a mineral, giving working agents access to the deposit as well as the mineral to the surface, are the basic components of geotechnological system (Khomenko, Sudakov, Malanchuk, \& Malanchuk, 2017; Dychkovskyi et al., 2018).

Hence, hydromechanical method of mineral mining should be considered as a complementary one rather than competitive with traditional techniques (Patvaros, 1985). It is expedient to use the methods for non-profitable deposits in the context of underground and open-pit mining: within large deposits of comparatively low-grade ore where significant economic effect may result from the production scale; within thin deposits and high-grade ore occurrences mined out using traditional methods to extract commercial components from the left pillars and out of balance ores; and within dumps of out of balance ores and mine tailings at closed mines and operating ones where amber is extracted (Belichenko \& Ladzhun, 2016).

Currently available technical means to implement a process of hydromechanical amber mining cannot satisfy in full modern demands; namely, the developed methods do not provide complete mining of commercial component from enclosing rocks. Moreover, they do not always use working liquid efficiently. Certain share of hydromechanical mining method factors are ignored by many researchers despite they are important for the productivity of hydromechanical mining facilities as well as for saving such resources as energy, water, and the mined commercial component amount (Honchar \& Fedoseienkov, 2016; Antoljak, Kuhinek, Korman, \& Kujundzic, 2018).

\section{EXPERIMENTAL STUDY}

The National University of Water and Environmental Engineering (town of Rivne, Ukraine) has developed hydromechanical method to buoy up amber within sandy deposit. Idea of the method is as follows: water-saturated rock mass is activated by means of mechanical stimulation (i.e. vibroexcitation) until continuous suspense layer is formed. Its density should be sufficient to force amber out to the deposit surface. That is if the rock mass contains water, mechanical action is applied to ruin attractions between particles completely, to release amber, and to help the medium achieve such suspense state which density is more than specific gravity of the amber which allows the latter buoying up at the expense of ascending force.

The method is implemented in this way: vibration is used to dip into amber-bearing rock mass rods in the form of pipes from which water is supplied and where vibration exciters are fastened. In the process, water saturates the rock mass; vibration exciters force it into vibration. Attractions between particles are ruined and amber buoys up.

Implementation of the method in the context of complete extraction makes it possible to prevent mineral raw materials from their getting to the deposit surface while mitigating technogenic environmental impact and increasing labour productivity with overall economic cost reducing (Malanchuk, Malanchuk, Korniyenko, \& Ignatyuk, 2017; Sokolov \& Udalov, 2017; Haiko, Saik, \& Lozynskyi, 2018). Currently, the means of vibration action on soil ground is widely used to drive in forestopes, pipes, cases, and pales; to develop soil and process it; to drill wells; and compact extremely loose and water saturated sandy soil. Usually, such facilities involve vibration generators (vibrators); vibration apparatus with vibration transmitters; equipment to gauge, and control vibration; and devices to prevent, to kill, and to isolate harmful transmission of vibration. Thus, the use of the hydraulic vibro intensifier to mine amber is more preferable to compare with other available methods (i.e. mechanical and hydraulic) since it helps achieve high level of amber mining, increase labour productivity 
while reducing energy consumption and mitigating negative technogenic environmental impact.

Experiments concerning determination of basic technological parameters of amber extraction from amberbearing deposits were carried out in the laboratory of the National University of Water and Environmental Engineering. The research is intended to analyze characteristics of amber-bearing deposit and to obtain data for analytical dependences of parameters of the method of hydromechanical amber extraction.

Northern area of Rivne Region is characterized mainly by amber occurrence in sandy soil which becomes sliding, if soil skeleton-water pores balance is disrupted and minor effect of hydraulic flows may result in the rock mass shift as well as soil bulk liquefaction. Watersaturated sand liquefaction provokes sand disturbance and its compaction due to the action of its own weight or due to external effects. During the process of sand underpressure, its bearing capability is exhausted either completely or partially; free-flowing condition arises, if sand structure is ruined, as well as mutual displacement of the sand particles followed by more compact particle arrangement and loss of porosity.

Underpressure phenomenon arises when structure ruins and sand can compact; when sand is water-saturated completely or is close to that state.

In the process of the research, amber-bearing sandy deposit becomes underpessured during the initial stage; then it compacts. Period of underpressure state of watersaturated sand is rather shorter to compare with soil compaction period.

Relying upon own opinion and scientific sources, the authors believe that compaction process is more studied than underpressure process; hence, experiments concerning underpressure process, a process of amber getting out to surface as well as a period during which sandy soil becomes compacted should involve further research. To create necessary conditions for amber getting to the surface, it is required to analyze parameters of vibration impact as well as water and air use while acting on sandy deposit.

Laboratory facility has been used to analyze amberbearing sand under laboratory conditions (Fig. 1). The facility was applied to model processes of sandy medium transition to boiling state; to carry out experimental research of underpressure medium; and to determine amber buoying up in the context of different vibration impacts as well as water and air supply.

The laboratory facility consists of a glass bank 1 (with $110 \times 110 \mathrm{~mm}$ dimensions, and $h=900 \mathrm{~mm}$ height) into which two hollow rods 2 for water and air are immersed. The rods are fastened on plate 3 to which water and air suppliers from water meter 4 and air meter 7 are connected. Mouthpieces with 1 to $1.5 \mathrm{~mm}$ diameter are located within every of the rods at 1200 angle. Water is supplied under 0 to $0.2 \mathrm{MPa}$ pressure. Air is supplied by means of a compressor under 0 to $0.2 \mathrm{MPa}$ pressure. Valves 5 and 6 are required to control water and air pressure. Plate 3 is located on hangers 8 . Glass bank is located on stationary frame 9 . Rods oscillate owing to impact mechanism with excentric 10 going by engine with the controlled rotational frequency.

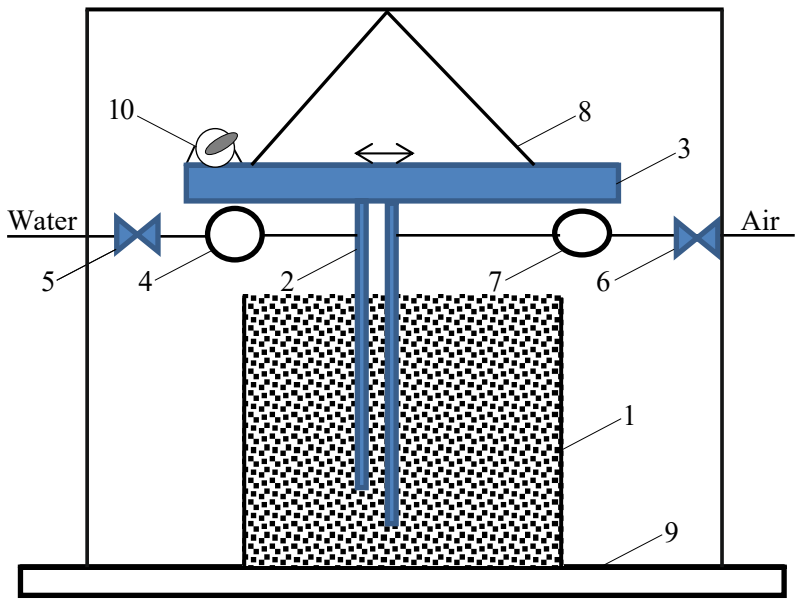

Figure 1. Laboratory facility: 1-glass bank; 2 -rods with mouthpieces to supply water and air; 3-plate; 4, 7-water meter and air meter; 5, 6-valves to control water and air supply; 8-flexible plate hangers; 9 -stationary frame; 10 -impact mechanism with excentric

In the process of the experimental research, the authors analyzed occurrence environment. Moreover, boiling process was analyzed; factors and parameters effecting suspense medium development were studied.

Rods have been immersed into freely filled up sandy medium with amber; they are used to aerate through a nozzle to supply gas. Intensity of the process varied; a zone of sandy rock mass with amber boiling was developed. Sand moisture varied owing to water addition. Both shape and geometry of boiling zone as well as amber movement within amber-bearing sand were studied. While analyzing boiling area of the sandy rock mass, when water and air were supplied, laboratory equipment was applied to measure the medium density as well as amber velocity buoying up to the sandy rock mass surface from $0.5-0.7 \mathrm{~m}$ depth. During the stage, the research range was as following: $0-0.2 \mathrm{MPa}$ for water pressure, and $0-0.2 \mathrm{MPa}$ for air pressure.

Following methods were used while analyzing with the help of the laboratory device:

- operating cylinder with sandy medium was mounted on the stationary frame; sandy medium height before water and air supply, and after it were measured as well as amber buoying up velocity;

- water and air were supplied in turn to the sandy medium through mouthpieces; together with pressure changes and different spending, similar measurements were performed;

- the studies were carried out repeatedly.

Full-scale studies were performed in cooperation with the experts of "Ukrainska Heolohichna Kompania" SE (Volyn Surveying Company, town of Kovel) in a village of Bereznytsia Volodymyrets District Rivne Region.

\section{RESULTS AND DISCUSSION}

The studies have helped determine that underpressure results in the destroyed structure of amber-bearing sandy medium. Those sand particles, available within oscillation zone, separate from the rock mass being forced into vibration as for their balanced position; moreover, they 
move along certain trajectory relative to vibration source. In this context, gas and water move intensively catching sand particles and amber and ejecting them to the surface. Since amber surface far exceeds surface of the particles, amber segments get to the surface under the action of buoyancy force.

The effect of vibration underpressure of a layer is similar to the effect of vibration linearization of dry friction, i.e. if oscillation is available, then to transfer relative motion to a particle within the medium, less permanent effort is required to compare with its nonavailability. When efficient friction coefficient decreases within vibration underpressure state, particles slide relative to each other with no release. The layer solidifies while flowing.

As studies inform, sand motion within vibroboiling layer is not subject to the law of particle motion in airfree space. In addition to gravitation, medium parameters effects heavily the motion trajectory of a sand layer. Underpressure is formed while tossing; pressurization results from falling down. Lower layers of sand experiences greater pressure difference to compare with upper ones since air is displaced from below and particles densify.

Hence, vibroboiling sand layer behaves like a pump delivering gas liquid mixture to the surface catching amber particles and transporting them up. In this context, buoying-up velocity of a particle depends upon vibration energizing of the rock mass, medium underpressure, saturation by air bubbles, and medium viscosity.

Pressure difference depends upon frequency of a vibration generator and its amplitude; layer height; particle size; sand moisture content; and a coefficient of mutual friction of the particles. Intensity of pumping action of vibroboiling layer is characterized by the three parameters: pressure over the vibroboiling layer, underpressure under it, and pressure difference within the layer.

Following factors effect formation of vibroboiling layer of a ground:

1) oscillation amplitude;

2) oscillation frequency;

3) exciting force;

4) water pressure;

5) air pressure;

6) geometry of vibration generators.

To a large degree, the parameters are determined experimentally.

When effector was acting on soil mass, the medium demonstrated its underpressure evaluated by means of vibroboiling layer poriness. Experiments have determined that the vibroboiling layer poriness depends upon vibration acceleration.

Air and water supply to sand mass helps intensify amber buoying up process up to the maximum values; however, if air columns are formed, boiling process transforms into vibration underpressure, and stops. Maximum velocity of amber buoying up to the surface is observed when gas liquid mixture supply to sand rock mass varies from 0 to $0.02 \mathrm{~m}^{3} /$ hour.

Formation of the required medium density depends on gas liquid mixture supply.

Our experimental data have been used to plot a curve of amber buoying up velocity dependence upon water and air supply (Fig. 2).

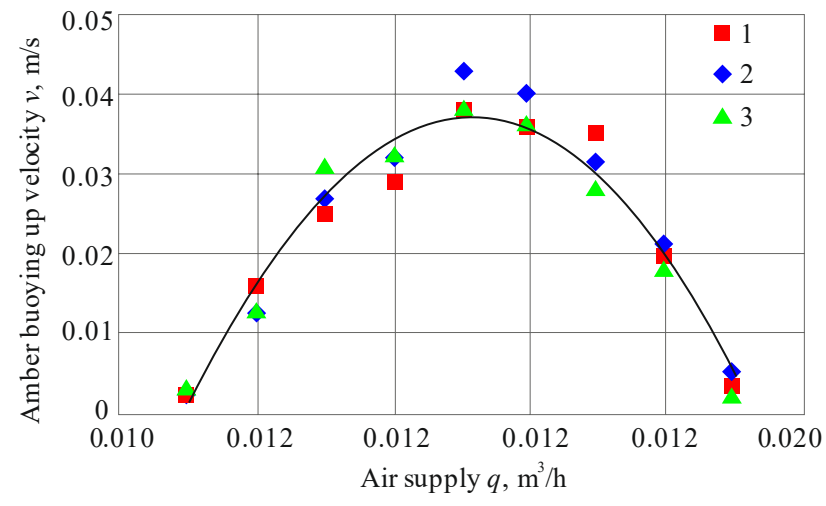

Figure 2. Amber buoying up velocity dependence upon air supply, if water supply is unvarying: 1 -under water supply; 2-under simultaneous water and air supply; 3 - under air supply

Taking into consideration the obtained experimental results, amber buoying up velocity dependence upon air supply is approximated as follows:

$v=-2113 q^{2}+64.12 q-0.449$,

where approximation reliability value is $R^{2}=0.953$.

If air is not supplied to ground, amber extraction process is performed with the help of hydraulic action. In this context, maximum amber buoying up velocity is $v=0.03-0.05 \mathrm{~m} / \mathrm{s}$ (Fig. 3).

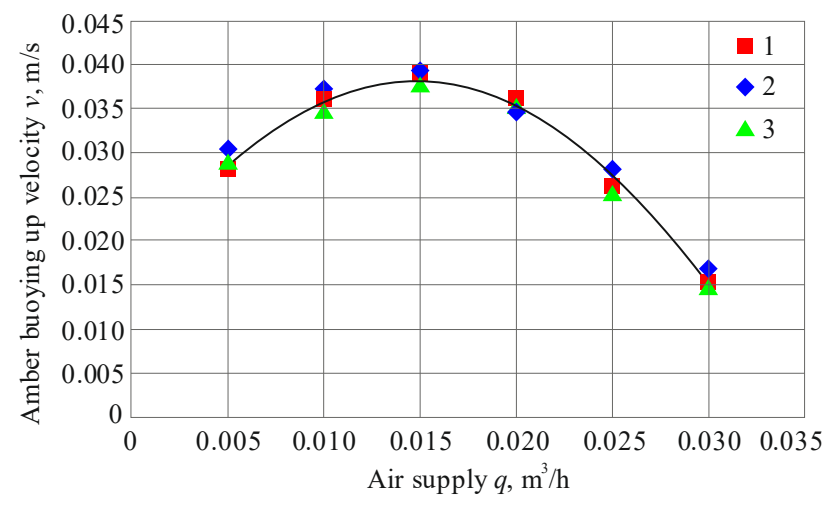

Figure 3. Amber buoying up velocity dependence, if water supply is $0.005-0.030 \mathrm{~m}^{3} / \mathrm{h}: 1$ - under the influence of vibration; 2 -under the influence of vibration and massif saturation by water; 3 -under massif saturation by water

Taking into consideration the obtained experimental results, amber buoying up velocity dependence upon water supply is approximated as follows:

$v=-105 q^{2}+3.115 q+0.015$,

where approximation reliability value is $R^{2}=0.991$.

Figure 4 shows the obtained experimental results concerning simultaneous effect of oscillation frequency of an effector and a value of air supply to sand demonstrating conspicuity of two peak areas of maximum amber buoying up velocity. Relying upon the obtained experimental dependence, the authors have determined following ranges of oscillations of effector, and value of air supply to amber-bearing rock mass. 


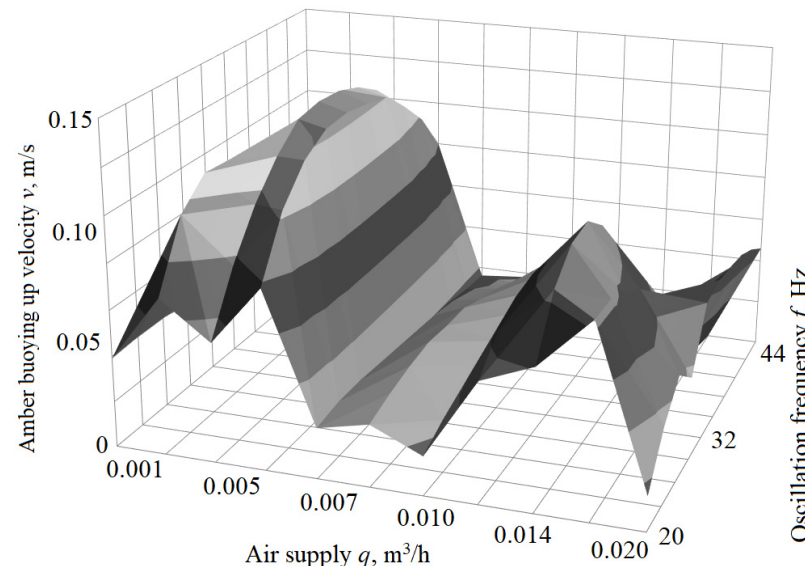

Figure 4. Amber buoying up velocity dependence on oscillation frequency and air supply to water saturated rock mass

Oscillation frequency of effector is $28-34 \mathrm{~Hz}$; a value of air supply to the rock mass is $0.003-0.006 \mathrm{~m}^{3} / \mathrm{h}$; in this context, amber buoying up velocity is the highest, i.e. $0.09-0.12 \mathrm{~m} / \mathrm{s}$.

Hence, the following was observed during the experiments carried out using laboratory equipment:

- amber buoying up velocity depends upon medium density; moreover, it has its own extremum;

- there are such values of water and air supply under which maximum velocity of amber buoying up to the surface are achieved;

- medium density effects heavily the conditions of amber getting to the surface;

- there are such values of water and air supply under which suspense medium is not formed and amber cannot buoy up to the deposit surface.

To carry out full-scale studies, effector was hanged to mobile frame crane using springy hook. The frame crane was applied to transport, to support, and to extract from the sandy rock mass (Fig. 5). From regulating valve, water and air are supplied to sandy rock mass with the help of hollows rods. Manometer has been mounted on the regulating valve to control pressure. Cone mouthpieces with cutters to ruin stagnant zones were fastened at the ends of all the rods. The rods were interconnected in packs coupled tightly with the plate.

Ranges of the device operating parameters are: working frequency range is $0-50 \mathrm{~Hz}$; amplitude is $0.08-2.50 \mathrm{~mm}$; liquid pressure is $0-0.2 \mathrm{MPa}$; and air pressure is $0-0.2 \mathrm{MPa}$. The device operates as follows. Using frame crane, it is mounted on the sand deposit. Drive is released to ge-nerate oscillations. When frame crane brings the equipment down, vibrator forces rods into sand. The rock mass is stimulated by means of oscillation action. Air and water are started to be supplied through the rods. The sand, being processed, experiences its underpressure up to the formation of continuous suspense layer. Amber pieces, getting to a zone of effector operation, loose their connections and buoy up to the surface under the action of buoyancy force and vibration forces. Air supply is added to intensify ground underpressure process. Frequency, oscillation amplitude, and exciting force are controlled by means of changes in rotation frequency of oscillation generator of an effector. (a)

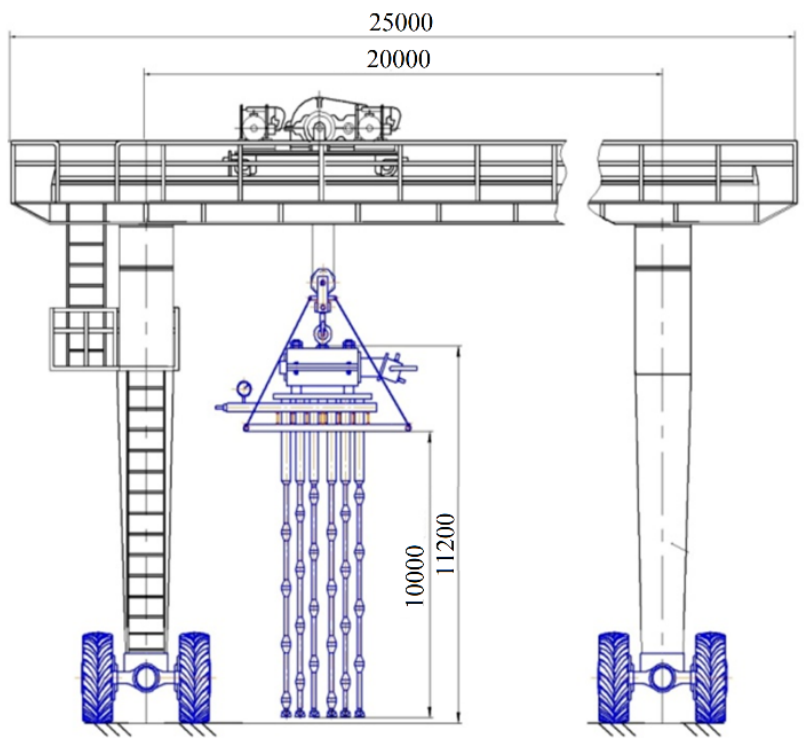

(b)

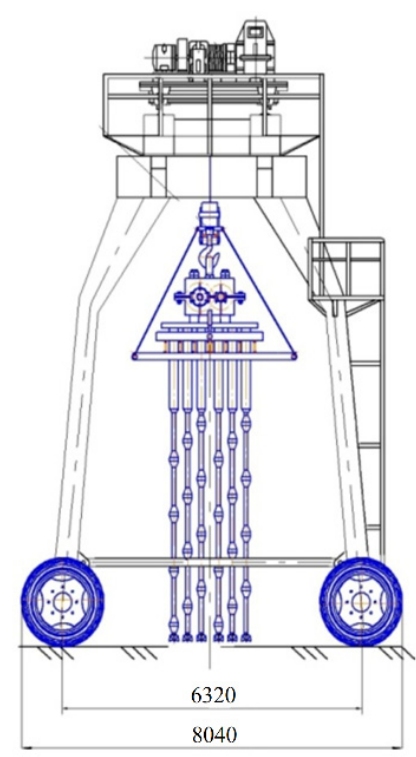

Figure 5. Device of hydromechanical amber extraction on the basis of a frame crane: (a) front view; (b) end view

The device deepens into the rock mass owing to own weight with the help of oscillations. The experiments, carried out within Volodymyrets amber deposit in Rivne Region, have helped understand that water quantity depends upon ground porosity within a rock mass being under development. While implementing the method, water filtration gradient outside the rock mass, being developed, can be ignored since the process is rapid one.

Air supply to sandy rock mass intensifies a process of amber buoying up. Increase in air consumption, exceeding rational ones, results in buoying up deceleration as well as formation of channels through which air passes freely to the deposit surface, and vibroboiling of the whole rock mass is not available.

Comparison of the device performance in terms of different modes, minimum density of sand medium (i.e. $1600 \mathrm{~kg} / \mathrm{m}^{3}$ ), formed by vibration generator, is observed under simultaneous water and air consumption, and wa- 
ter consumption without water when vibration frequency is $26-36 \mathrm{~Hz}$.

The device operation demonstrated the determined working zone of the suspended ground as well as its boiling process with hard amber pieces bringing to the surface of the soil rock mass.

Velocity of amber getting to the surface depended upon the process intensity, namely upon action of effector oscillations, gas-air mixture supply, and physical and chemical properties of the soil.

The following was observed during the research:

- amber buoying up velocity depends upon oscillation frequency of an effector, amplitude of the medium and its density; moreover, it has its extremum;

- medium density effects heavily the creation of conditions for rapid amber buoying up in turn effecting the efficiency of hydromechanical method of amber extraction;

- there are such values of oscillations, and water and air supply in terms of which suspense medium is not generated, and amber cannot get to the deposit surface.

It is possible to intensify amber mining process, if oscillations are used and water (or water and air) is supplied to the rock mass.

The required medium density depends upon gas liquid mixture, oscillation frequency, and geometry of an effector as well as its weight. Water supply depends upon the medium underpressure period.

Relying upon the experiment results, dependences of the medium density $\left(\rho_{c}\right)$, amber buoying up velocity $(v)$, and intensifier frequency $(A)$ upon frequency oscillations $(f)$ are approximated as follows (Fig. 6):

- if medium density is $\left(\rho_{c}\right)$, then:

$\rho_{c}=1.93 f^{2}-126.32 f+3740.5$,

where approximation reliability value is $R^{2}=0.996$;

- if amber buoying up velocity is $(v)$, then:

$v=-1.1 \cdot 10^{-3} f^{2}+0.0612 f-0.7451$,

where approximation reliability value is $R^{2}=0.943$;

- if intensifier amplitude is $(A)$, then:

$A=0.0024 f^{3}-0.22 f^{2}+6.29 f-56.46$,

where approximation reliability value is $R^{2}=0.974$.

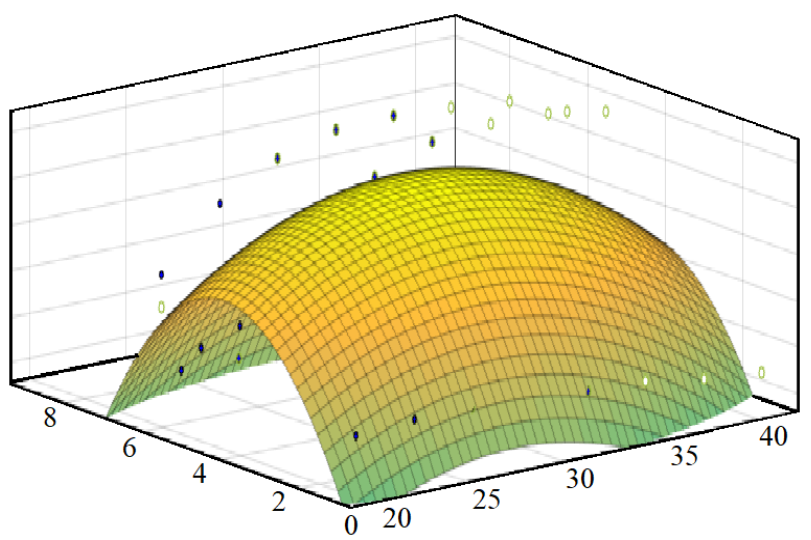

Figure 6. Amber buoying up velocity dependence on oscillation frequency and air supply in the context of fullscale studies
Experimental studies has helped determine rational medium density $\left(\rho_{c}=1670-1750 \mathrm{~kg} / \mathrm{m}^{3}\right)$ achieved by means of $26-36 \mathrm{~Hz}$ oscillation frequency; $A=1.0-2.4 \mathrm{~mm}$ amplitude, and $q_{a}=0.004-0.006 \mathrm{~m}^{3} / \mathrm{h}$ air supply when amber buoying up velocity is $v=0.09-0.12 \mathrm{~m} / \mathrm{s}$.

In the context of full-scale studies, maximum amber buoying up velocity (with gas liquid mixture supply) was observed when oscillation frequency was $26-36 \mathrm{~Hz}$, and air supply was $0.004-0.007 \mathrm{~m}^{3} / \mathrm{h}$.

Taking into consideration the experiment results, the dependence of amber buoying up velocity $(v)$ on oscillation frequency $(f)$ and air supply $(q)$ is approximated as follows:

$$
\begin{aligned}
& v=-0.033 q^{2}+0.0031 q f-0.0059 f^{2}- \\
& -0.018 q+0.0097 f+0.109
\end{aligned}
$$

where approximation reliability value is $R^{2}=0.704$.

First of all, the experiments have confirmed efficiency of the hydromechanical method to extract amber as well as the method acceptance to be applied for amber mining from local deposits.

During the experiments when $100 \%$ of amber was extracted (i.e. the amount of amber in place coincided with the amber amount have been mined) no rock returns to the deposit surface were observed. The mine working excavation supported nonavailability of cavities; the experiments confirmed environmental safety of the method. The technique is implemented with minimum amount of recultivation operations required for overburden activities, minimum transport cost, and minimum water supplied with $0.1-0.2 \mathrm{MPa}$ pressure. The above confirms high energy performance and economic efficiency of the method.

\section{CONCLUSIONS}

Currently, amber extraction needs innovative technologies as well as the improved facilities to intensify extraction process when higher productivity and efficiency are achieved. Moreover, mitigated environmental impact is also involved. The studies have determined experimental dependences; regularities of the effect of hydromechanical method parameters to extract amber from sandy deposits as for its mining velocity have been determined.

The determined dependencies make it possible to identify the basic parameters influencing the velocity of amber getting to the surface. According to the obtained results, medium density, oscillation amplitude and frequency, air and water supply to amber-bearing sand are the parameters. The studies have helped determine experimental dependencies; moreover, regularities of the effect of hydromechanical method of amber extraction from amber-bearing deposits have been confirmed. They help mine up to $90-95 \%$ of amber. The studies have made it possible to identify amber extraction parameters; among other things, it concerns oscillation frequency of an effector and its amplitude, and air and water consumption to provide the highest intensity of amber buoying up. Furthermore, an expression to calculate amber buoying up velocity depending upon oscillation frequency and air supply has been deduced. 


\section{ACKNOWLEDGEMENTS}

The studies have been carried out on the basis of the National University of Water and Environmental Engineering (town of Rivne), and with the participation of the experts from "Ukrainska Heolohichna Kompania" SE (Volyn Surveying Company, town of Kovel). The authors express thanks to a Vice-Rector for Research of the National University of Water and Environmental Engineering, Doctor of Ecological Sciences N.B. Savina for the opportunity to perform the research using laboratory equipment of the University, and to the authorities of "Ukrainska Heolohichna Kompania" SE for joint research within Volodymyrets amber-bearing deposit (a village of Bereznytsia).

\section{REFERENCES}

Alekseev, V.I. (2013). The beetles (Insecta: Coleoptera) of Baltic amber: the checklist of described species and preliminary analysis of biodiversity. Zoology and Ecology, 23(1), 5-12. https://doi.org/10.1080/21658005.2013.769717

Antoljak, D., Kuhinek, D., Korman, T., \& Kujundzic, T. (2018). Dependency of specific energy of rock cutting on specific drilling energy. Rudarsko Geolosko Naftni Zbornik, 33(3), 23-32. https://doi.org/10.17794/rgn.2018.3.3

Belichenko, O., \& Ladzhun, J. (2016). Complex gemological research of new types of treated amber. Visnyk of Taras Shevchenko National University of Kyiv. Geology, 4(75), 30-34.

https://doi.org/10.17721/1728-2713.75.04

Bondarenko, V., Lozynskyi, V., Sai, K., \& Anikushyna, K. (2015). An overview and prospectives of practical application of the biomass gasification technology in Ukraine. New Developments in Mining Engineering 2015: Theoretical and Practical Solutions of Mineral Resources Mining, 27-32. https://doi.org/10.1201/b19901-6

Bulat, A., Naduty, V., \& Korniyenko, V. (2014). Substantiations of technological parameters of extraction of amber in Ukraine. American Journal of Scientific and Educational Research, 5(2), 591-597.

Burnashov, E., Chubarenko, B., \& Stont, Z. (2010). Natural evolution of western shore of the Sambian Peninsula on completion of dumping from an amber mining plant. Archives of Hydro-Engineering and Environmental Mechanics, 57(2), 105-117.

Dychkovskyi, R.O., Lozynskyi, V.H., Saik, P.B., Petlovanyi, M.V., Malanchuk, Ye.Z., \& Malanchuk, Z.R. (2018). Modeling of the disjunctive geological fault influence on the exploitation wells stability during underground coal gasification. Archives of Civil and Mechanical Engineering, 18(4), 1183-1197. https://doi.org/10.1016/j.acme.2018.01.012

Haiko, H., Saik, P., \& Lozynskyi, V. (2018). The philosophy of mining: Historical aspect and future prospect. Philosophy \& Cosmology, (22), 76-90. https://doi.org/10.29202/phil-cosm/22/6

Haldar, S.K. (2013). Mineral exploration - case histories. Mineral Exploration, 287-322. https://doi.org/10.1016/b978-0-12-416005-7.00001-5

Havelcová, M., Machovič, V., Linhartová, M., Lapčák, L., Přichystal, A., \& Dvořák, Z. (2016). Vibrational spectroscopy with chromatographic methods in molecular analyses of Moravian amber samples (Czech Republic). Microchemical Journal, (128), 153-160. https://doi.org/10.1016/j.microc.2016.04.010

Honchar, A., \& Fedoseienkov, S. (2016). Geo- and hydroacoustic complex as a study of interconnection between processes in waters and bottom sediments. Geodynamics, 21(2), 101-108.

https://doi.org/10.23939/jgd2016.02.101

Khomenko, O.Ye., Sudakov, A.K., Malanchuk, Z.R., \& Malanchuk, Ye.Z. (2017). Principles of rock pressure energy usage during underground mining of deposits. Naukovyi Visnyk Natsionalnoho Hirnychoho Universytetu, (2), 34-43.

Korniyenko, V.Ya., Malanchuk, E.Z., Soroka, V.S., \& Khrystyuk, A.O. (2018). Analysis of the existent technologies of amber mining. Resources and resource-saving technologies in mineral mining and processing, 209-232.

Krek, A., Ulyanova, M., \& Koschavets, S. (2018). Influence of land-based Kaliningrad (Primorsky) amber mining on coastal zone. Marine Pollution Bulletin, (131), 1-9. https://doi.org/10.1016/j.marpolbul.2018.03.042

Krümmelbein, J., Horn, R., Raab, T., Bens, O., \& Hüttl, R.F. (2010). Soil physical parameters of a recently established agricultural recultivation site after brown coal mining in Eastern Germany. Soil and Tillage Research, 111(1), 19-25.

$\mathrm{Li}$, D. (2014). Underground hydraulic mining of thin sub-layer as protective coal seam in coal mines. International Journal of Rock Mechanics and Mining Sciences, (67), 145-154. https://doi.org/10.1016/j.ijrmms.2014.01.014

Lozynskyi, V., Saik, P., Petlovanyi, M., Sai, K., Malanchuk, Z., \& Malanchuk, Y. (2018). Substantiation into mass and heat balance for underground coal gasification in faulting zones. Inzynieria mineralna, (2), 289-300. https://doi.org/10.29227/IM-2018-02-36

Lozynskyi, V.G., Dychkovskyi, R.O., Falshtynskyi, V.S., Saik, P.B., \& Malanchuk, Ye.Z. (2016). Experimental study of the influence of crossing the disjunctive geological fault on thermal regime of underground gasifier. Naukovyi Visnyk Natsionalnoho Hirnychoho Universytetu, (5), 21-29.

Malanchuk, Z., Korniienko, V., Malanchuk, Ye., Soroka, V., \& Vasylchuk, O. (2018). Modeling the formation of high metal concentration zones in man-made deposits. Mining of Mineral Deposits, 12(2), 76-84. https://doi.org/10.15407/mining12.02.076

Malanchuk, Z., Korniyenko, V., Malanchuk, Y., \& Khrystyuk, A. (2016). Results of experimental studies of amber extraction by hydromechanical method in Ukraine. Eastern-European Journal of Enterprise Technologies, 3(10(81)), 24-28. https://doi.org/10.15587/1729-4061.2016.72404

Malanchuk, Z., Malanchuk, Y., Korniyenko, V., \& Ignatyuk, I. (2017). Examining features of the process of heavy metals distribution in technogenic placers at hydraulic mining. Eastern-European Journal of Enterprise Technologies, $1(10(85)), 45-51$

https://doi.org/10.15587/1729-4061.2017.92638

Malanchuk, Z., Moshynskyi, V., Malanchuk, Y., \& Korniienko, V. (2018). Physico-mechanical and chemical characteristics of amber. Solid State Phenomena, (277), 80-89. https://doi.org/10.4028/www.scientific.net/ssp.277.80

Malanchyk, Z., \& Korniyenko, V. (2014). Modern condition and problems of extraction of amber in Ukraine. Canadian Journal of Science and Education, 6(2), 372-376.

Naduty, V., Malanchuk, Z., Malanchuk, Y., \& Korniyenko, V. (2016). Research results proving the dependence of the copper concentrate amount recovered from basalt raw material on the electric separator field intensity. Eastern-European Journal of Enterprise Technologies, 5(5(83)), 19-24. https://doi.org/10.15587/1729-4061.2016.79524

Patvaros, J. (1985). Integrating effect of hydromechanizationin mining technological systems. Acta Geodaetica, Geophysica Et Montanistica Hungarica, 20(4), 447-451.

Paynter, S., \& Jackson, M.C. (2018). Mellow yellow: An experiment in amber. Journal of Archaeological Science: Reports, (22), 568-576. https://doi.org/10.1016/j.jasrep.2017.11.038 
Poulin, J., \& Helwig, K. (2016). The characterization of amber from deposit sites in western and northern Canada. Journal of Archaeological Science: Reports, (7), 155-168. https://doi.org/10.1016/j.jasrep.2016.03.037

Radwanek-Bąk, B., \& Nieć, M. (2015). Valorization of undeveloped industrial rock deposits in Poland. Resources Policy, (45), 290-298. https://doi.org/10.1016/j.resourpol.2015.07.001

Saik, P.B., Dychkovskyi, R.O., Lozynskyi, V.H., Malanchuk, Z.R., \& Malanchuk, Ye.Z. (2016). Revisiting the underground gasification of coal reserves from contiguous seams. Naukovyi Visnyk Natsionalnoho Hirnychoho Universytetu, (6), 60-66.

Sazonets, I., \& Malanchuk, L. (2015). A substantiation of economic feasibility of the development of copper deposits in Rivne-Volyn region. International Journal of New Economics and Social Sciences, 2(2), 116-120.

https://doi.org/10.5604/01.3001.0010.4733
Seyfullah, L.J., Sadowski, E.M., \& Schmidt, A.R. (2015). Species-level determination of closely related araucarian resins using FTIR spectroscopy and its implications for the provenance of New Zealand amber. PeerJ, (3), e1067. http://doi.org/10.7717/peerj.1067

Sokolov, V.A., \& Udalov, I.V. (2017). Mineral and raw material base of agronomical ore in Kharkiv region. Visnyk of V.N. Karazin Kharkiv National University. Series Geology, Geography, Ecology, (47), 206-210. https://doi.org/10.26565/2410-7360-2017-47-27

Van der Werf, I.D., Fico, D., De Benedetto, G.E., \& Sabbatini, L. (2016). The molecular composition of Sicilian amber. $\mathrm{Mi}$ crochemical Journal, (125), 85-96. http://doi.org/10.1016/j.microc.2015.11.012

\title{
ЗАКОНОМІРНОСТІ ПРОЦЕСУ ГІДРОМЕХАНІЧНОГО ВИЛУЧЕННЯ БУРШТИНУ 3 ПШЩАНИХ ПОКЛАДІВ
}

\author{
Є. Маланчук, В. Корнієнко, В. Мошинський, В. Сорока, А. Христюк, 3. Маланчук
}

Мета. Дослідження ефективності процесу гідромеханічного вилучення бурштину з піщаних покладів на основі встановлених закономірностей впливу параметрів шляхом проведення серії лабораторних та натурних експериментів.

Методика. Експериментальним шляхом в лабораторних та польових умовах (Володимирецьке бурштиновмісне родовище, с. Бережниця) проведено дослідження впливу параметрів гідромеханічного способу вилучення на швидкість підняття бурштину. При проведенні експериментальних досліджень вивчалось середовище залягання, при цьому проводилось моделювання процесу кипіння й дослідження факторів і параметрів, що впливають на створення суспензного середовища. Із використанням методів математичної статистики отримано залежності, що описують вплив параметрів вилучення на швидкість підняття бурштину.

Результати. Визначено основні параметри гідромеханічного методу, що впливають на швидкість вилучення бурштину. Встановлено раціональні значення величини подачі повітря для забезпечення максимальної швидкості спливання бурштину. Отримано математичні залежності, що визначають швидкість спливання залежно від по-дачі повітря та частоти механічного впливу, при цьому рівень видобутку бурштину сягає $90-95 \%$. Визначені основні параметри, які впливають на інтенсивність підняття бурштину на денну поверхню, - густина середовища, амплітуда та частота коливань, подача води й повітря у піщане родовище бурштиновмісного піску.

Наукова новизна. Вперше доведено, що швидкість спливання бурштину має поліноміальний характер залежності від густини середовища з екстремумом при величині подачі повітря $0.004-0.006 \mathrm{~m}^{3} /$ год, а вилучення бурштину інтенсифікується у $2-3$ рази при густині робочого середовища $\left(\rho_{c}\right) 1670-1750 \mathrm{\kappa r} / \mathrm{M}^{3}$, частоті коливання $26-36$ Гц, амплітуді $A=1.0-2.4$ мм, подачі повітря $q_{a}=0.004-0.006 \mathrm{~m}^{3} /$ год, при цьому швидкість спливання бурштину $(v)$ рівна $0.09-0.12 \mathrm{~m} / \mathrm{c}$, а при збільшенні подачі повітря понад $0.020 \mathrm{M}^{3} /$ год процес вилучення бурштину припиняється. Вперше отримано поліноміальну залежність швидкості спливання бурштину від частоти коливань робочого органу та подачі повітря в масив.

Практична значимість. Визначені закономірності гідромеханічного вилучення бурштину із бурштиновмісних пісків дозволяють проводити розрахунок та обирати обладнання для проведення гідромеханічного видобутку бурштину.

Ключові слова: піщаний поклад, бурштин, гідромеханічний видобуток, подача повітря, швидкість спливання

\section{ЗАКОНОМЕРНОСТИ ПРОЦЕССА ГИДРОМЕХАНИЧЕСКОГО ИЗВЛЕЧЕНИЯ ЯНТАРЯ ИЗ ПЕСЧАНЫХ ЗАЛЕЖЕЙ}

\section{Е. Маланчук, В. Корниенко, В. Мошинский, В. Сорока, А. Христюк, З. Маланчук}

Цель. Исследование эффективности процесса гидромеханического извлечения янтаря из песчаных залежей на основе установленных закономерностей влияния параметров путем проведения серии лабораторных и натурных экспериментов.

Методика. Экспериментальным путем в лабораторных и полевых условиях (Владимирецкое янтарное месторождение, с. Бережница) проведено исследование влияния параметров гидромеханического способа извлечения на скорость всплытия янтаря. При проведении экспериментальных исследований изучалась среда залегания, при этом проводилось моделирование процесса кипения и исследование факторов и параметров, влияющих на создание суспензионной среды. С использованием методов математической статистики получены зависимости, описывающие влияние параметров извлечения на скорость всплытия янтаря.

Результаты. Определены основные параметры гидромеханического способа, влияющие на скорость извлечения янтаря. Установлены рациональные значения величины подачи воздуха для обеспечения максимальной 
скорости всплытия янтаря. Получены математические зависимости, определяющие скорость всплытия в зависимости от подачи воздуха и частоты механического воздействия, при этом уровень добычи янтаря достигает 90 - 95\%. Определены основные параметры, влияющие на интенсивность всплытия янтаря на дневную поверхность, - плотность среды, амплитуда и частота колебаний, подача воды и воздуха в песчаное месторождение янтарного песка.

Научная новизна. Впервые доказано, что скорость всплытия янтаря имеет полиномиальный характер зависимости от плотности среды с экстремумом при величине подачи воздуха $0.004-0.006 \mathrm{~m}^{3} /$ ч, а извлечение янтаря интенсифицируется в $2-3$ раза при плотности рабочей среды $\left(\rho_{c}\right) 1670-1750$ кг/м ${ }^{3}$, частоте колебания $26-36$ Гц, амплитуде $A=1.0-2.4$ мм, подачи воздуха $q_{a}=0.004-0.006 \mathrm{~m}^{3} /$ ч, при этом скорость всплытия янтаря (v) равна $0.09-0.12 \mathrm{~m} / \mathrm{c}$, а при увеличении подачи воздуха более $0.020 \mathrm{~m}^{3} /$ час процесс извлечения янтаря завершается. Впервые получена полиномиальная зависимость скорости всплытия янтаря от частоты колебаний рабочего органа и от подачи воздуха в массив.

Практическая значимость. Установленные закономерности гидромеханического извлечения янтаря с янтарных песков позволяют производить расчет и выбирать оборудование для проведения гидромеханической добычи янтаря.

Ключевые слова: песчаная залежь, янтарь, гидромеханическая добыча, подача воздуха, скорость вспльтия

\section{ARTICLE INFO}

Received: 7 August 2018

Accepted: 16 January 2019

Available online: 30 January 2019

\section{ABOUT AUTHORS}

Yevhenii Malanchuk, Doctor of Technical Sciences, Professor of the Department of Automation, Electrical Engineering and Computer-Integrated Technologies, National University of Water and Environmental Engineering, 11 Soborna St, 33028, Rivne, Ukraine. E-mail: malanchykEZ@gmail.com

Valerii Korniienko, Doctor of Technical Sciences, Professor of the Department of Development of Deposits and Mining, National University of Water and Environmental Engineering, 11 Soborna St, 33028, Rivne, Ukraine. E-mail: kvja@i.ua

Viktor Moshynskyi, Doctor of Agricultural Sciences, Professor of the Department of Land Management, Cadaster, Land Monitoring and Geoinformatics, National University of Water and Environmental Engineering, 11 Soborna St, 33028, Rivne, Ukraine. E-mail: v.s.moshynskyi@nuwm.edu.ua

Valerii Soroka, Candidate of Agricultural Sciences, Associate Professor of the Department of Transport Technologies and Maintenance, National University of Water and Environmental Engineering, 11 Soborna St, 33028, Rivne, Ukraine. E-mail: vssoroka@i.ua

Andriy Khrystyuk, Candidate of Technical Sciences, Associate Professor of the Department of Automation, Electrical Engineering and Computer-Integrated Technologies, National University of Water and Environmental Engineering, 11 Soborna St, 33028, Rivne, Ukraine. E-mail: a.khrystyuk@gmail.com

Zinovii Malanchuk, Doctor of Technical Sciences, Professor of the Department of Development of Deposits and Mining, National University of Water and Environmental Engineering, 11 Soborna St, 33028, Rivne, Ukraine. E-mail: malanchykzr@ukr.net 